\title{
Glanzmann thrombasthenia
}

INSERM

\section{Source}

INSERM. (1999). Orphanet: an online rare disease and orphan drug data base. Glanzmann thrombasthenia. ORPHA:849

Glanzmann thrombasthenia (GT) is a bleeding syndrome characterized by spontaneous mucocutaneous bleeding and an exagg erated response to trauma due to a constitutional thrombocytopenia. 